Board of Governors of the Federal Reserve System

International Finance Discussion Papers

Number 602

January 1998

\title{
REGIONALISM AND PERMANENT DIVERSION
}

\author{
Caroline L. Freund
}

NOTE: International Finance Discussion Papers are preliminary materials circulated to stimulate discussion and critical comment. References in publications to International Finance Discussion Papers (other than an acknowledgment that the writer has had access to unpublished material) should be cleared with the author or authors. Recent IFDPs are available on the Web at www.bog.frb.fed.us. 


\title{
REGIONALISM AND PERMANENT DIVERSION
}

\author{
Caroline L. Freund*
}

\begin{abstract}
We compare free trade reached through expanding regional trading blocks to free trade accomplished by multilateral negotiation. With sunk costs, the outcomes are different. Trade in an imperfectly competitive good flows disproportionately more between the original members of a regional agreement even after free trade is reached. They secure a higher welfare level from regionalism than from free trade achieved multilaterally; non-members, however, reach a lower welfare level. A surprising result is that world welfare during free trade is greater when it is achieved by the regional path. We conclude with some empirical evidence from the European Union that is consistent with the model.
\end{abstract}

Keywords: imperfect competition, sunk costs, preferential trade agreements.

"Economist in the International Finance Division of the Federal Reserve Board. I am very grateful to Jagdish Bhagwati, Kyle Bagwell, and John McLaren for many useful discussions. I also benefitted from comments from Alessandra Casella, Simeon Djankov, Simon Evenett, Philip Lane, Catherine Mann, Usha Nair, Seamus O'Cleireacain, Francisco Rivera-Batiz, Dani Rodrik, John Rogers, Maurice Schiff, Neeraja Sivaramayya, Kei-Mu Yi, and seminar participants at Clemson, Columbia, Federal Reserve Board, Texas A\&M, World Bank, and The Empirical Investigations in International Trade Conference. The views in this paper are solely the responsibility of the author and should not be interpreted as reflecting the views of the Board of Governors of the Federal Reserve System or of any other person associated with the Federal Reserve System. 


\section{Introduction}

This paper examines the long run effect that regional trade areas have on trade. The basic idea is that if trade is associated with sunk costs then there is going to be path dependency and some of the trade diversion that results from the free trade areas may not be reversed when the blocs are dissolved. This implies that free trade achieved through regional expansion may look quite different - in terms of the trade flows between countries and the welfare of each country - from free trade achieved via non-preferential agreements. ${ }^{1}$

The related literature on regionalism has recently focussed on the dynamic question of whether preferential trade agreements (PTAs) will help or hinder the multilateral process. Krugman 1992, Bond and Syropoulos 1996, Bagwell and Staiger 1997, and Haveman 1996 examine optimal tariffs in the presence of exogenously formed customs unions. Their findings suggest that PTAs have an ambiguous effect on tariffs and welfare. Krugman shows that if countries are symmetric, optimal tariffs rise and welfare falls as number of unions declines; however, if unions are formed by countries with relatively low transport costs-i.e. natural trading partners-then trade and welfare rises as the number of unions declines. Bond and Syropoulos, in a repeated game framework, find that the optimal tariff equilibrium with expanding customs unions depends on the endowments of the member countries. Also in a repeated game setting, Bagwell and Staiger 1997 show that, following a honeymoon period of multilateral tariff reduction, regional agreements will lead member countries to raise tariffs. Finally, Haveman finds that while unrestricted PTAs are likely to worsen welfare; if GATT

\footnotetext{
${ }^{1}$ Regional agreement, bilateral trade agreement, and preferential trade agreement are used interchangeably in this paper.
} 
rules are strictly enforced, the sequential expansion of PTAs will improve welfare.

Another strand of the literature analyzes optimal tariffs and PTAs under the assumption that governments care relatively more about certain sectors of the economy. While Baldwin 1993 and Richardson 1993 conclude that regionalism can speed up the tariff reduction process; Grossman and Helpman 1995, Levy 1993, and Krishna 1994 show that trade diversion plays a key role in the members' incentives to form a union and hence that members may be less inclined to reduce tariffs after a PTA is formed.

This paper addresses a different set of questions: (i.) What are the long run consequences for trade and welfare if free trade is achieved through preferential agreements as opposed to multilateral negotiation? And, (ii.) Is there any reason why a country would prefer one path to another? These questions are important because a growing literature suggests that sunk costs are involved in developing an export sector. ${ }^{2}$ With sunk costs, regionalism will have persistent effects on trade flows, implying countries will sign regional agreements not only to attain preferential market access now, but also because they can retain their market share if free trade is achieved. Thus, if the world is moving toward free trade, permanent market share gains abroad may provide a reason why countries prefer the regional path.

To answer the questions posed above we develop a model with imperfect competition and sunk costs. Then we look at the outcome if competition is in quantity. With imperfect competition, output is too low and trade improves welfare by strengthening competitive

\footnotetext{
${ }^{2}$ Several recent studies have focused on the importance of sunk costs and hysteresis in trade. The major theoretical contributions are Baldwin and Krugman 1989 and Dixit 1989. Feinberg 1992, Campa 1993, Roberts and Tybout 1997, and Eichengreen and Irwin 1996 find empirical evidence of hysteresis in trade.
} 
forces. We find that a regional agreement before free trade leads to a greater expansion in world output than immediate free trade because it creates a strategic incentive for member countries to increase exports to each other's market. That is, since sunk costs allow firms to effectively pre-commit to exports in the future, firms will take into account the effect of an increase in exports now on the quantity firms from other countries will export in the future. This leads to higher production of the imperfectly competitive good when free trade is achieved following a regional agreement.

We show that countries that are pioneering members of free trade agreements get most of the benefits, if sunk costs to expand trade and investment are first realized within their borders. Comparing the welfare associated with free trade achieved via regionalism to that of free trade achieved via multilateral negotiation, we find that the primary members of expanding trading blocs attain a higher level of welfare from the regionalism path, while late entrants fall to a lower level of welfare. Moreover, world welfare in the second period is actually greater from the regional path. The gains to the original members are greater than the loss to the late member, implying there is no compensation the late member can offer the initial members to be permitted at the start.

Assuming the regional path is pursued and free trade is achieved, we also examine which countries would form a union first. We find that large countries prefer to sign a PTA with each other initially. A larger share of a bigger market is better than a larger share of a smaller market. We also find that countries would rather form a trade bloc with the higher cost producer. The market share gains abroad outweigh the consumer surplus loss at home.

Next we look at the outcome if competition is in price rather than quantity. In the 
model developed here, the second period results are robust to price competition. Output in the original member countries is higher in the free trade period after a regional agreement as compared to free trade in both periods and they retain a greater market share abroad. Output in the non-member is lower.

Finally, we examine trade data from the European Union to see if observed trade flows are consistent with the predictions of the model. The European Union serves as a natural experiment since it expanded from six members in 1958 to twelve in 1986 . The model suggests that the founding six will trade more with one another than with countries that entered the union at a later date. The gravity equation is used as a basis by which to test the importance of the date of entry. While there is little evidence that the original members traded more with each other than was predicted by the gravity equation before the common market was created, by 1962 the original members of the European Union traded over 65\% more with each other and by 1970 the founders traded more than twice as much with each other than with the non-members. In 1990, the six still traded over $75 \%$ more with each other than with the non-members. The empirical evidence is thus consistent with the market share results predicted by the model.

This paper is divided into five sections. The next section develops the model, the third section extends the model, the fourth provides some empirical evidence, and the last section concludes. 


\section{Model}

The model below shows that regional agreements will lead to persistent effects on trade and welfare, even if free trade is ultimately achieved. Permanent effects from regional agreements arise if firms undertake irreversible investment before free trade is achieved. Specifically, firms incur two types of costs in getting their product to market, a production cost and a distribution network cost, both based on quantity. In a two period game, we assume that the cost of the distribution network inherited in the second period is sunk. A firm's marginal cost will then be lower in the second period since it is just the production cost. Thus, whenever incumbent firms compete with new entrant firms they have a cost advantage. In a model of imperfect competition their Cournot output will be higher than the Cournot quantities produced by the new entrants.

Welfare gains to the original members arise because their firms export more to each others' market than if they had never signed a regional agreement. During free trade, firms from the original member nations retain a larger market share in their partner country and therefore higher producer surplus abroad than if there had been free trade initially. In addition, since domestic sales are higher, consumer surplus at home is greater when free trade is achieved. The intuition is that firms use their distribution network strategically to develop a permanent hold on a market. When firms invest in the partner country they keep in mind the effect of their investment on the future output decisions of firms from the non-member nation. Market-specific sunk costs allow the incumbent firms to effectively pre-commit to higher trade levels than they would under free trade in both periods in order 
to attain a larger market share in the future.

The results are strongest for countries with highly concentrated industries since the gains from increased competition will be the largest. They are generated by the leadership advantage original members are given via regionalism. While regionalism before free trade essentially allows the firms in the initial member countries to act as Stackelberg leaders in trade, going directly to free trade forces firms in all countries to make simultaneous export decisions. Stackelberg leadership arises endogenously because of the regional agreements and is credible owing to the sunk costs associated with the distribution network. The additional gains to the original members from sequential entry are thus absent in a one time multilateral free trade agreement, since it forces firms from all of the countries to compete symmetrically in each others' markets.

We next develop the model explicitly.

\subsection{Assumptions}

We consider three identical countries, A, B, and C, each with $\mathrm{n}$ firms in the imperfectly competitive industry. Following Brander and Krugman's 1983 reciprocal dumping model, trade is in a homogenous good, competition is Cournot, and welfare gains are a result of the increase in competition that trade introduces. Sunk costs are involved in setting up and supporting a product distribution network, all of which are assumed to be specific to the destination country in question. ${ }^{3}$ Sunk costs can explain why the market for the good is

\footnotetext{
${ }^{3}$ Another paper that looks at the interaction of sunk costs and regional agreements is McLaren 1995. He shows that a small country can be worse off after forming a PTA with a large country, than under trade
} 
imperfectly competitive and ultimately are at the root of permanent effects.

\subsection{Timing}

The game has two periods and there is perfect information. Within each period there are two stages. In the first stage governments set policy and in the second stage output is produced and traded. Policy consists of: (i.) forming a regional agreement, (ii.) allowing free trade, or (iii.) autarky. We assume that only two of the countries, A and B, perhaps because of regional proximity, have the option to form a regional agreement. In this case, they have zero bilateral tariffs, but do not allow imports in the imperfectly competitive good from the third country, C. Otherwise, the governments choose between total free trade and autarky. 4

In the first period, after governments choose trade policy, firms choose output. All firms can commit to domestic distribution first, hence effectively committing to output at home. After choosing domestic distribution, each firm decides on exports. In the second period, the game repeats itself; except, after governments commit to policy, all firms choose output simultaneously, for each market in which they are permitted to participate.

war, if there is a possibility of future trade negotiations. The small country looses bargaining power once sunk costs to expand the export sector have been expended.

${ }^{4}$ We assume an all or nothing trade policy in the imperfectly competitive good sector - trade or no trade, i.e. no tariffs. The inclusion of non-prohibitive tariffs or quotas does not change the results but serves to complicate the algebra and make the mechanism less transparent. It can, however, reduce the magnitude of the effects. 


\subsection{Market structure}

Demand for the imperfectly competitive good in each country is defined by:

$$
P=K-Q
$$

where $P$ is price, $K$ is a constant, and $Q$ is total output. The markets here are assumed to be segmented, that is, it is prohibitively costly to cross-haul output. ${ }^{5}$

Costs for each firm, in a given market, are defined as follows in their first period of production:

$$
c=w q+x q
$$

where $x$ is the variable cost of the distribution network, $q$ is quantity, and $w$ is the variable cost of production. In the second period, a firm that has already set up a distribution network faces the following cost function:

$$
c=w q+x \max (q, q *)
$$

where $q *$ is the quantity chosen in the first period. This implies that the cost of the distribution network is fixed if output is less than or equal to first period output; therefore, the firm's second period marginal cost is lower than its first period marginal cost.

By setting up a distribution network for $q *$, in the first period, the firm shifts out the

\footnotetext{
${ }^{5}$ Evidence of pricing to market is consistent with widely-observed deviations from the law of one price. Moreover, Engel and Rogers 1996 find that the law of one price holds more closely within regions - they speculate that this may be the result of integrated marketing and distribution systems.
} 


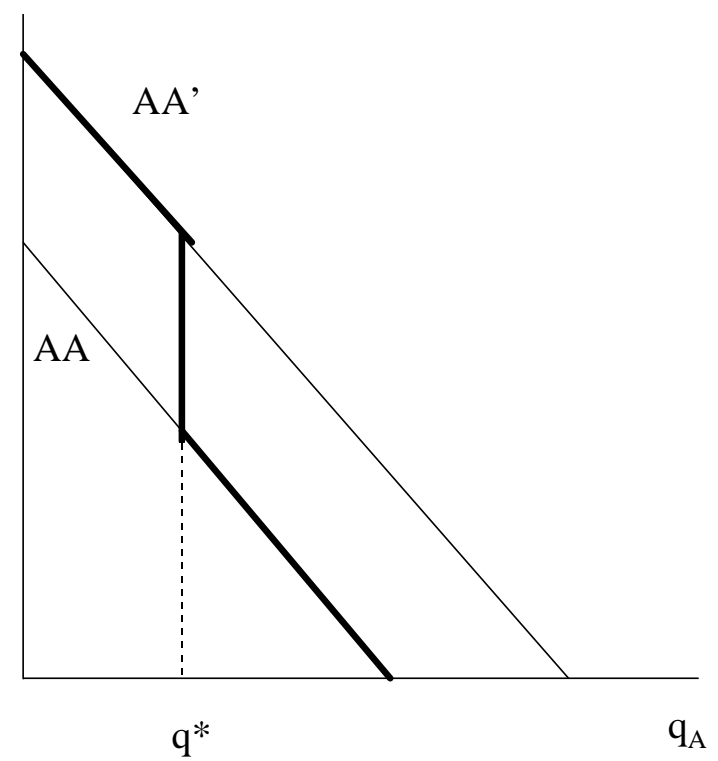

Figure 1: The reaction function of a firm

reaction function it shows to other firms in the next period. ${ }^{6}$ Figure 1 shows the reaction function of a firm with a marginal cost of $w+x(A A)$ and the reaction function of a firm with a marginal cost of $w\left(A A^{\prime}\right)$. Since a firm with an established distribution network has a marginal cost of $w$ for output below $q *$ and $w+x$ for output above $q *$, it presents the bold reaction function to other firms. The key feature of this reaction function is the vertical segment. No matter how much the competitors produce, within this range, it remains optimal for the firm to produce $q *$.

\footnotetext{
${ }^{6}$ For a complete description of this type of cost function and its effect on a two firm market, see Dixit 1980.
} 


\section{Solving the model}

We are now ready to solve the model. There are several paths that need to be examined, but some can be ruled out immediately. A welfare maximizing government will always prefer some trade to no trade. In addition, no country will ever choose to go from free trade to regionalism. If free trade is optimal in the first period, it must be in the second as well. The same is not true of regionalism to free trade, since regionalism affects the free trade outcome. The main question becomes: will countries A and B choose regionalism followed by free trade or free trade in both periods? Since firms are profit maximizing, the government knows how they will behave under each policy scenario and will choose the path that maximizes welfare. We consider two scenarios: regionalism followed by free trade and free trade in both periods.

\subsection{Country A: the regional path}

We start by looking at the equilibrium output levels in market A, assuming A and B choose to exclude $\mathrm{C}$ in the first period and have complete free trade in the second period. The main result is that $\mathrm{A}$ and $\mathrm{B}$ hold onto a greater share of each others market even after free trade is achieved.

\subsubsection{The firm's problem}

The problem is solved backwards. First, we solve for second period Cournot quantities and then we solve for first period output. For now, we assume that each firm from country A and country $\mathrm{B}$ is on the vertical part of its reaction function; hence, each will produce the same amount in both periods. In the next section, we provide the conditions under which 
full commitment is feasible and optimal.

The objective of each firm from country $\mathrm{C}$ is to maximize profits with respect to exports to country A. The problem is thus:

$$
\max _{z_{C}} z_{C}\left(K-n q_{B, 2}^{A}-n q_{A, 2}^{A}-(n-1) n q_{C, 2}^{A}-z_{C}-w-x\right)
$$

where $q_{j, k}^{i}$ is the quantity for sale in country $i$, by a firm from country $j$, in the $k t h$ period, $z_{i}$ is the output of a representative firm from country $i$, and $z_{i}=q_{i, 2}^{A}$ in equilibrium.

In the first period, each firm in B maximizes profits taking into account the effect of today's output choice on tomorrow's profits. Since the quantities do not change between periods, the time subscript is dropped. The optimization problem, for a firm from B, is:

$$
\begin{aligned}
& \max _{z_{B}} z_{B}\left[K-n q_{A}^{A}-(n-1) q_{B}^{A}-z_{B}-w-x\right]+ \\
& \beta z_{B}\left[K-n q_{A}^{A}-n q_{C}^{A}\left(n q_{A}^{A},(n-1) q_{B}^{A}, z_{B}\right)-(n-1) q_{B}^{A}-z_{B}-w-x\right],
\end{aligned}
$$

where $\beta$ is the rate of time preference. ${ }^{7}$

Each firm in country A chooses its distribution network before each firm from B, so we have:

$$
\begin{aligned}
& \max _{z_{A}} z_{A}\left[K-(n-1) q_{A}^{A}-z_{A}-n q_{B}^{A}\left((n-1) q_{A}^{A}, z_{A}\right)-w-x\right]+ \\
& \beta z_{A}\left[K-(n-1) q_{A}^{A}-z_{A}-n q_{B}^{A}\left((n-1) q_{A}^{A}, z_{A}\right)-\right. \\
& \left.n q_{C, 2}^{A}\left((n-1) q_{A}^{A}, z_{A}, n q_{B}^{A}\left((n-1) q_{A}^{A}, z_{A}\right)\right)-w-x\right],
\end{aligned}
$$

Solving equations (4), (5), and (6) yields the equilibrium quantities:

$$
q_{A}^{A}=\frac{(K-w-x)}{(n+1)}, \quad q_{B}^{A}=\frac{(K-w-x)}{(n+1)^{2}}, \quad q_{C, 2}^{A}=\frac{(K-w-x)}{(n+1)^{3}} .
$$

\footnotetext{
${ }^{7}$ Rather than thinking of $\beta$ as a number less than one, $\beta$ could also be larger than one if we think of the second period as lasting longer than the first period.
} 
Note that the quantity of each firm from A is the Stackelberg leadership quantity with respect to a firm from B or C. The quantity of a firm from B is the Stackelberg leadership quantity with respect to a firm from $\mathrm{C}$ and a Stackelberg follower quantity with respect to a firm from A.

\subsubsection{Credible commitment with entry}

The quantities, $q_{A}^{A}$ and $q_{B}^{A}$ above, are credible in the second period only if each incumbent firm would not wish to reduce its quantity once firms from $\mathrm{C}$ have entered. That is, if the Cournot quantity in period two with a marginal cost of $w$, is greater than or equal to the quantity chosen in period one. The condition that must be satisfied for each firm in country $\mathrm{A}$, in the second period, is the following:

$$
q_{A}^{A} \leq \frac{\left(K-w-n q_{B}^{A}-n q_{C}^{A}\right)}{(n+1)}
$$

The left hand side of (8) is the optimal quantity that we solved for above. The right hand side of (8) is the Cournot quantity that the same firm wants to produce in the second period, given that its marginal cost is $w$. If the right hand side of (8) is strictly greater than the left hand side, then the firm is on the vertical portion of its reaction function. Plugging the quantities from (7) into (8) and simplifying, we have:

$$
\frac{x}{K-w-x} \geq \frac{n^{2}+2 n}{(n+1)^{3}} .
$$

If (9) holds, then each firm in A has no incentive to reduce quantity in the second period, even after firms from the other countries have entered their market.

To gauge the necessary magnitude of the sunk costs, this condition can be written as the 
distribution cost relative to the markup, as follows:

$$
\frac{\text { distribution } \cos t}{\text { markup }} \geq n^{2}+2 n \text {. }
$$

There is a corresponding condition for the credible commitment of each firm from B in A's market. It is less stringent than the condition on a firm from A, since each firm from B produces less than each firm from A. The condition for a firm from B reduces to:

$$
\frac{\text { distribution } \cos t}{\text { markup }} \geq n
$$

This implies that provided the sunk part of the variable cost, $\mathrm{x}$, is large enough, firms from A and B can pre-commit to their Stackelberg leadership quantities. ${ }^{8}$

\subsubsection{Country C}

How much will firms from A and B export to C? Firms from A and B enter C's market simultaneously. Each firm will thus solve the following maximization in the period when it enters C's market:

$$
\max _{z_{A B}} z_{A B}\left(K-n q_{C}^{C}-(2 n-1) q_{A B}^{C}-z_{A B}-w-x\right)
$$

where $z_{A B}$ is the output from a representative firm from A or B produced for country C.

If firms from $\mathrm{A}$ and $\mathrm{B}$ enter in the second period, each firm from $\mathrm{C}$ will solve the following maximization problem:

$$
\max _{z_{C}} z_{C}\left(K-(n-1) q_{C}^{C}-z_{C}-w-x\right)+
$$

\footnotetext{
${ }^{8}$ If the distribution cost is zero, firms have no commitment capability and the outcome will be symmetric. If it is greater than zero, but permits less than full commitment, a firm will produce its maximum credible commitment.
} 


$$
\beta z_{C}\left(K-(n-1) q_{C}^{C}-z_{C}-2 n q_{A B}^{C}\left((n-1) q_{C}^{C}, z_{C}\right)-w-x\right)
$$

If firms from $\mathrm{A}$ and $\mathrm{B}$ enter in the first period the corresponding problem is:

$$
\begin{aligned}
& \max _{z_{C}} z_{C}\left(K-(n-1) q_{C}^{C}-z_{C}-2 n q_{A B}^{C}\left((n-1) q_{C}^{C}, z_{C}\right)-w-x\right)+ \\
& \beta z_{C}\left(K-(n-1) q_{C}^{C}-z_{C}-2 n q_{A B}^{C}\left((n-1) q_{C}^{C}, z_{C}\right)-w-x\right) .
\end{aligned}
$$

Solving, in either case, yields:

$$
q_{C}^{C}=\frac{K-w-x}{n+1}, \quad q_{A B}^{C}=\frac{K-w-x}{(n+1)(2 n+1)} .
$$

Note that since the countries are symmetric, if A's leadership quantity at home is credible, then C's must be as well.

Country C's optimal policy What is the optimal trade policy choice for country C? In the first period, country $\mathrm{C}$ chooses between autarky and allowing imports from $\mathrm{A}$ and $\mathrm{B}$. Figure 2 shows C's market if firms from A and B are allowed to enter. The loss in profits is a wash since it is also a gain in consumer surplus. There is a net gain of $S$ in consumer surplus. Thus, welfare from free trade in both periods is always higher so $\mathrm{C}$ will allow free trade in both periods. ${ }^{9}$ (See appendix for proof).

\subsection{Trade after regionalism}

If free trade is achieved in the second period following a bilateral agreement in the first period, trade between founding members will be greater than trade between an initial member

\footnotetext{
${ }^{9}$ We can assume that there is always free trade in the competitive good so that $\mathrm{C}$ does not run a deficit in the fist period. Or, we can assume that there is no trade between the trade block members and $\mathrm{C}$ in the first period, the welfare results do not change.
} 


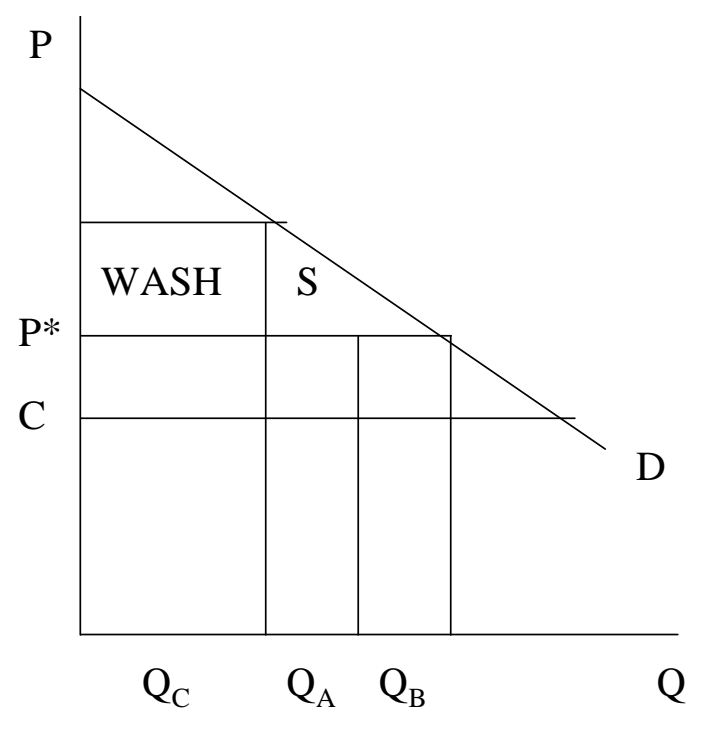

Figure 2: Country C

and a new member. The permanent expansion in trade, as a result of the preferential trade agreement between the original members, is at the heart of the welfare gains that accrue to the founders. In addition, while the welfare implications of the model are not testable empirically, the necessary pre-condition-that trade should be relatively greater among founding members-can be tested.

To see that trade is greater among the original members we look at bilateral trade flows. From (7) we can determine A's imports from B and C:

$$
n q_{B}^{A}=\frac{n(K-w-x)}{(n+1)^{2}} \geq \frac{n(K-w-x)}{(n+1)^{3}}=n q_{C}^{A},
$$

hence A imports more from B than from C. And from (7) and (15) we can examine A's exports to B and C:

$$
n q_{A}^{B}=\frac{n(K-w-x)}{(n+1)^{2}} \geq \frac{n(K-w-x)}{(n+1)(2 n+1)}=n q_{A}^{C},
$$


thus A exports more to B than to C.

With sunk costs, when free trade is achieved, trade in the imperfectly competitive good is greater between the initial members of a regional agreement than between the late entrant and an initial member. If sunk costs are not important, trade flows can adjust and trade patterns will be symmetric during the free trade period. Or, if there is free trade in both periods trade will always be symmetric.

\subsection{Multilateral path}

The multilateral path implies that the firms from both trading partners enter each country simultaneously. The problem, for all countries now, will look identical to the problem above for country $\mathrm{C}$ - in terms of imports and domestic sales - except that all countries will be identical, i.e. trade flows will be perfectly symmetric.

\subsection{Welfare analysis}

In this section, we examine the implications for welfare from the regional path to free trade versus the multilateral negotiation path. First we show that a country in a regional agreement will always want free trade in the second period. Then we compare welfare from the two paths.

\subsubsection{Country A}

Figure 3 shows A's market after free trade reached through regionalism. The price is $P^{R}$ during the period of regional trade and $P^{*}$ during the period of free trade. Since the quantity 


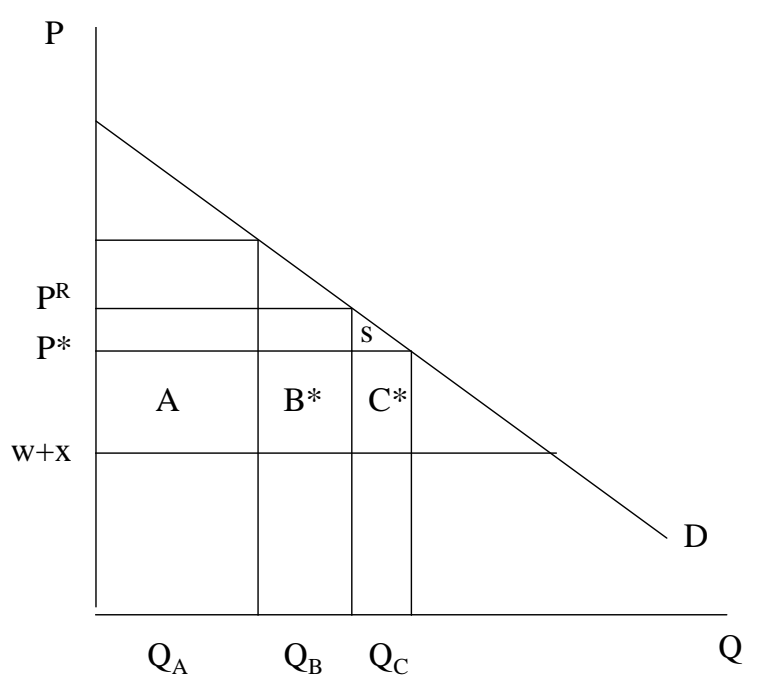

Figure 3: Country A

produced by the home firms does not change when $\mathrm{C}$ enters, the gain in consumer surplus must outweigh the loss in profits. There will be a net gain of $s$, when firms from $\mathrm{C}$ enter and therefore governments will always prefer to have free trade.

Welfare is the sum of producer and consumer surplus. In the first period - the regional trade period - output is lower and the price is higher than if there was free trade. As a result, first period welfare is lower than if there was free trade.

In the free trade period, welfare expands as a result of a regional agreement in the previous period. In contrast to free trade in both periods, profits to firms from A in country B are greater. Domestic profits fall since the price is lower; while, the profits in $\mathrm{C}$ are the same regardless of the path. The loss in profits at home outweighs the gain in profits abroad, so total profits, accruing to firms in A, are lower in free trade after a regional agreement than with two free trade periods. ${ }^{10}$

\footnotetext{
${ }^{10}$ This result coincides with the political economy literature which shows that a regional agreement can
} 
The total quantity after regionalism is bigger than the total quantity after multilateralism. Consumer surplus after regionalism must therefore also be larger than consumer surplus after multilateralism. The gain in consumer surplus exceeds the loss in profits since the decline in profits at home is completely offset by a gain in consumer surplus.

In sum, the original members of a bilateral agreement are at a lower welfare level in the first period, and a higher welfare level in the second period, from having a regional agreement before free trade, relative to choosing free trade in both periods. If the periods are the same length, or the second period is longer, they will prefer the regional path to free trade.(This is also true if $\mathrm{C}$ does not allow imports in the first period. See appendix for proof).

The intuition is that the regional path allows premier members to get a larger share of profits abroad in both periods and a larger gain in consumer surplus at home in the second period than the multilateral approach. ${ }^{11}$

\subsubsection{Welfare from regionalism: country $\mathrm{C}$}

Now let's look at the new entrant. In the first period, profits abroad are zero, since C cannot export. Consumer surplus is the same as it would be if there was multilateral free trade. Therefore, total welfare is lower during the regional period.

In the second period after a regional agreement, producer surplus is still lower than if there had been free trade in the first period. Domestic profits are the same regardless of the reduce the incentives to get to free trade. If producers have political pull they will be less willing to go to free trade after a regional agreement than they were initially - profits are reduced by more.

${ }^{11}$ This will be true, in general, provided when one firm increases production by one unit other firms together decrease output by less than one unit, and thus total output increases. 
path. Profits abroad, the area $\mathrm{C}^{*}$ in Figure 3, are lower in free trade after regionalism, since they export less and get a lower price for exports.

Consumer surplus is the same regardless of the path since the quantity in C's market is the same. But, total profits are lower, so welfare in country $\mathrm{C}$ is lower after free trade reached through regionalism.

Firms in country $\mathrm{C}$ lose on two accounts if free trade is achieved via regionalism: one, they are excluded from the foreign market in the first period; and two, in the second period they have less scope for expansion abroad, since firms from A and B have cornered the market. Thus, the late entrant to a regional agreement obtains a higher welfare level from free trade reached multilaterally than from entering a regional agreement previously signed by the other nations.

\subsubsection{World welfare}

World welfare from the regional path to free trade is actually higher than world welfare from the multilateral path. This is because, in the second period, the amount the early entrants gain from free trade reached through a regional agreement is greater than the amount the late entrant loses. (See appendix for proof). The logic is that regionalism leads to greater total output since there is a strategic incentive for the firms from the trade bloc countries to expand exports. This implies that even if side payments are feasible and countries care sufficiently about the second period, the non-member cannot bribe the regional bloc countries to allow free trade in the first period, because the members' gains are greater than what the non-member would be willing to pay. 
Since the members are the winners and the non-members are the losers, all countries will want to join the region as soon as possible. So, if all countries have access to a regional agreement, just the announcement of regionalism should lead to immediate multilateral free trade. Similar to Baldwin 1993 there will be a strong snowball effect.

\section{Extensions}

If everyone wants to be among the initial members of a trading bloc which countries will be the original entrants? In this section, we consider some extensions to the model above. We examine differences in market structure to discover which countries will want to form a region first. We also show that the second period results are not reversed under price competition.

\subsection{Asymmetric countries}

\subsubsection{Cost differences}

First we look at what happens if the three countries produce the good in question at different constant marginal production costs, $w_{A} \neq w_{B} \neq w_{c}$. In this case, for simplicity we look only at second period welfare, we assume that there is only one firm in each country, and that $x$ is large enough to make the Stackelberg leadership quantities credible.

What happens to welfare in country A from taking the regional path to free trade? Welfare in country A $\left(W^{A}\right)$ is the sum of profits and consumer surplus:

$$
W^{A}=\Pi_{A}^{A}+\Pi_{A}^{B}+\Pi_{A}^{C}+C S^{A}
$$


where $\Pi_{A}^{i}$ is the profits of domestic firms in country i and $C S^{A}$ is consumer surplus in A. In the second period, this simplifies to:

$$
\begin{aligned}
= & \frac{\left(K-x-4 w_{A}+2 w_{B}+w_{C}\right)^{2}}{16}+\frac{\left(K-x-6 w_{A}+4 w_{B}+w_{C}\right)^{2}}{32}+ \\
& \frac{\left(K-x-5 w_{A}+w_{B}+3 w_{C}\right)^{2}}{36}+\frac{\left(7 K-7 x-4 w_{A}-2 w_{B}-w_{C}\right)^{2}}{128} .
\end{aligned}
$$

The first term is profit at home, the second term is profit is the partner country, the third term is profit in the late entrant nation, and the last term is consumer surplus at home. A's welfare is increasing in both $w_{B}$ and $w_{C}$, however A's welfare increases more with $w_{B}$ than $w_{C}$, that is:

$$
\frac{d W^{A}}{d w_{B}}>\frac{d W^{A}}{d w_{C}},
$$

for reasonable values of $K, w_{A}, w_{B}, w_{C}$. (See appendix for proof). This implies that A would rather form an initial bilateral agreement with the higher cost producer first! Lower costs in the partner country have two opposing effects: they imply lower profits in their market and lower consumer surplus at home. The first effect dominates and countries would rather form a bilateral agreement with the higher cost producer. This case is disturbing since the low cost producer will end up producing less than with non-preferential treatment.

World welfare, however, is decreasing in production costs.

$$
\begin{gathered}
W W=W^{A}+W^{B}+W^{C}, \\
\frac{d W W}{d w_{i}}<0, \quad \text { for all } i, \text { and } \\
\quad\left|\frac{d W W}{d w_{B}}\right|>\left|\frac{d W W}{d w_{C}}\right| .
\end{gathered}
$$


This implies that world welfare is higher if the low cost countries form the agreement first. If the lowest cost countries form a region, more is produced worldwide, which leads to greater welfare. But, lower cost countries would never have the incentive to team up first.

\subsubsection{Different market sizes}

The case of different market sizes, where $K_{A} \neq K_{B} \neq K_{C}$, is very intuitive. Each country would prefer to get a larger share of a bigger market, that is:

$$
\frac{d W_{A}}{d K_{B}}>\frac{d W_{A}}{d K_{C}}
$$

As a result, the larger countries would team up first.

\subsection{Price competition}

In this section, we test the robustness of the results to price competition. We find that in the members' markets, in the second period following a regional agreement, the two main results both survive. That is, the pro-competitive effect and the market share gains that accrue to the members are both present or neutral if there is price competition and differentiated products.

The intuition is that creating a large distribution network in the first period still makes a firm more aggressive in the second period. ${ }^{12}$ During the period of bilateral trade there are fewer firms serving the market so each firm is faced with a greater demand. Each firm will thus want to create a larger distribution network than if there was overall free trade. In the

\footnotetext{
${ }^{12}$ Competition is in price, but commitment is in still quantity and quantity is what affects a firm's future marginal cost.
} 


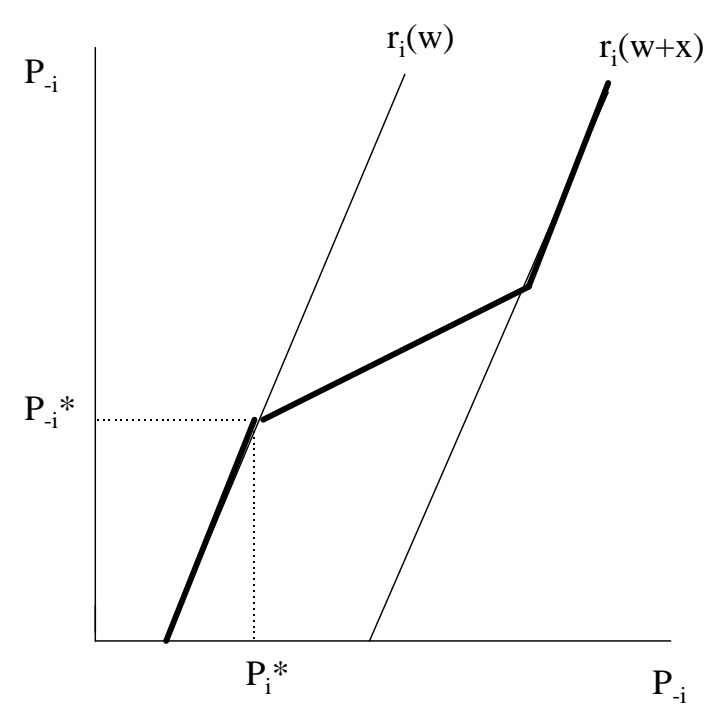

Figure 4: Price competition

second period, all firms in the market will be subject to stronger price competition than in the absence of the agreement since the members' marginal costs are lower for a wider range of outputs.

In this case, investment in a large distribution network is a strategic disadvantage to the firm, since it makes the firm less able to hold price high in the second period. For example, in Figure $4, r_{i}(w+x)$ is firm $i^{\prime}$ s price reaction function with a marginal cost of $w+x$; and, $r_{i}(w)$ is firm $i$ 's reaction function with a marginal cost of $w$. At the point, $\left(p_{i}^{*}, p_{-i}^{*}\right)$, (where $p_{-i}^{*}$ is the price level of the other firms), firm $i$ is selling a quantity equal to the capacity of its inherited distribution network. ${ }^{13}$ If the other firms raise price slightly, firm $i$ 's

\footnotetext{
${ }^{13}$ This is assuming the other firms' prices affect the firms profits identically. If not, the graph could represent the firms reaction function, with respect to one firm's price, holding all other firms prices constant. The same argument will still hold provided all products are demand substitutes and strategic complements in price.
} 
demand increases, firm $i$ responds by holding its quantity constant and raising prices. This accounts for the diagonal line connecting the two reaction functions. Along this diagonal the firm temporarily stops adjusting output, and adjusts only price. Only when demand is high enough to justify selling a unit with a marginal cost of $w+x$, will the firm be on the reaction function $r_{i}(w+x)$.

The diagonal which connects the two reaction functions will be higher up if firm $i$ produces more in the first period. In that case, the firm will be on the reaction function $r_{i}(w)$ for a larger range of prices offered by its competitors. This implies price competition is more severe. Because there are fewer firms in the market in the first period under regionalism, the temptation is to sell more than if there was overall free trade (assuming price reaction functions are upward sloping). But, selling more in the first period puts the firm at a strategic disadvantage in the second period. The firm will maximize over the gain from lowering its price in the first period and the negative effect that it has on future profits. The firm will therefore never produce less under bilateral trade than it would under free trade. ${ }^{14}$

Notice that the firm cannot do better than the reaction function $r_{i}(w+x)$. With multilateral free trade in both periods, the same equilibrium would ensue in both periods and it would be on $r_{i}(w+x)$. Thus, a bilateral agreement in the first period can only serve to increase the quantity and lower the price level realized in the partner countries in the second period. Hence, regionalism still expands or leaves unchanged quantity in the member coun-

\footnotetext{
${ }^{14}$ Suppose that a firm sets price so that the quantity is the same with two firms in the market, as it would be with three firms. At the price offered, the temptation must be to lower price (and produce more) since there is a positive effect on current profits, and the negative effect on second period profits is zero at that point.
} 
tries and trade between them in the second period. ${ }^{15}$ While the competitive effect survives, the overall welfare results are less clear because of the negative impact on product diversity that the expansion in partner country goods would generate.

The firm from the non-member nation, however, does not have a distribution network in place and thus faces a higher marginal cost abroad in the second period. That firm, therefore, has a smaller market share than in the absence of the regional agreement. The firm from the non-member still loses from the agreement because the price it sets must be at a lower point on its reaction function, since the other firms will be charging lower prices. In addition, the price level in the non-member nation must be higher since the foreign firms entered simultaneously.

\section{$5 \quad$ Empirical evidence}

A natural testing ground for the model presented above is the European Union. Entry into the Union was staggered, the original members - France, Germany, Italy, Belgium, Luxembourg, and the Netherlands - formed the European Economic Community in 1958. Britain, Ireland, and Denmark were the next to join in 1973; they were followed by Greece in 1981, Portugal and Spain in 1986; and more recently, Austria, Finland, and Sweden became

\footnotetext{
${ }^{15}$ Perhaps a better way to formulate this problem under price competition, would be to follow the methodology used in Maggi 1996. Maggi assumes that installing additional capacity is more costly than it was initially. He finds that the equilibrium varies between the Cournot and Bertrand benchmark, depending on how costly additional capacity is.
} 
members in $1995 .^{16}$

Using the gravity model to adjust for "normal" trade flows, this section examines data from the EU countries to determine whether the formation of the Union affected the pattern of trade flows among members. The main results are consistent with the hypothesis that early entry into a union allows countries to establish trade links that persist over time.

\subsection{The gravity equation}

The basic gravity equation postulates that bilateral trade flows are a function of the size of the trading partners and the distance between them. The hypothesis is that trade is increasing in income and decreasing in distance, or:

$$
t r_{i j}=\frac{Y_{i} Y_{j}}{D I S_{i j}}
$$

where $t r_{i j}$ is trade flows from country $i$ to country $j, Y_{i(j)}$ is i's (j's) income, and $D I S_{i j}$ is the distance between the countries. ${ }^{17}$ Other studies have found that trade flows fit this simple model surprisingly well.

By including a dummy variable which represents countries in a PTA, the gravity equation is often used to explain deviations from "normal" trade as a result of preferential trade agreements. Frankel, Stein, and Wei 1994 employ this approach to determine regional bias in

\footnotetext{
${ }^{16} \mathrm{It}$ is too soon to observe effects on the the most recent entrants so we do not include Austria, Finland, and Sweden in the sample.

${ }^{17}$ Note that the gravity model is consistent with the model of trade presented earlier. The equations we want to test are equations (16) and (17). The number of firms (n) will be increasing with the size of a country and the partner's demand (K-Q) will also increase with its size. Distance raises costs (w), implying that exports are decreasing in distance.
} 
trade. They find that regional groupings have significantly altered trade flows; the European Community, for example, has encouraged its members to trade $63 \%$ more with each other in 1990 than the gravity model predicts. Eichengreen and Irwin 1996 also look at the effect of PTAs on trade flows using historical data from 1949 to 1964 . Their motive is to analyze not only the effect of regional agreements but also the effect of history on trade flows. They argue that any analysis which does not include historical trade flows in the regression equation may overestimate the effects of bloc membership since the formation of the union may be an attempt by primary trading partners to insulate themselves from global shocks. In order to account for historical effects they propose using lagged trade in the gravity model.

To test the effect of order of entry on trade flows we use a similar approach to Frankel, Stein, and Wei and Eichengreen and Irwin. The following hypothesis is tested: in the years since the formation of the EU, trade between the original six members is larger than the otherwise natural trade flow as predicted by the gravity model and thus also relative to the other members. We also suspect that trade between the late entrants and the incumbent members will be below the natural trade flows predicted by the gravity model. First we estimate a gravity equation on all the EU member nations for five years between 1954 to 1990 and look at the coefficient on the dummy variable representing the founding members. We then include trade from 1950 in the regression equation, as a proxy for initial conditions.

We test the hypothesis by examining bilateral trade flows between EU member nations for 1954, 1962, 1970, 1980, and 1990. The countries included are Britain, France, Germany, Greece, Italy, Ireland, the Netherlands, Belgium-Luxembourg, Denmark, Spain, and 
Portugal. ${ }^{18}$ Since we are looking at exports from one country to another there are 110 data points $\left(11^{*} 10\right)$. The model we fit is the following:

$$
\log t r_{i j}=\beta_{0}+\beta_{1} \log \left(Y_{i} Y_{j}\right)+\beta_{2} \log \left(y_{i} y_{j}\right)+\beta_{3} \log D I S+\beta_{4} A D J+\beta_{5} D I F P C+\beta_{6} O R G
$$

where $y_{i}$ is per capita income in country i, $A D J$ is a dummy variable that is one if the countries share a border, DIFPC is the natural logarithm of the difference in the partners' per-capita incomes, and $O R G$ is a dummy variable that equals one if both countries are original members and is zero otherwise. The hypothesis above implies that $\beta_{6}$ will be positive in all years following the formation of the union. There are two alternative hypotheses: one, that the union has no effect in which case $\beta_{6}$ will be zero; and two, that unions are formed by natural trade partners, in this case $\beta_{6}$ should be significantly greater than zero even before the formation of the union.

The first five columns in Table 1 show the results. The variable $O R G$ is positive and significant in all four years after the customs union was formed. The gradual tariff reductions prescribed under The Treaty of Rome were completed in 1969, so it is not surprising that the coefficient on $O R G$ is greatest in 1970-during this year the members traded more than twice as much with each other than predicted by the gravity model $(\exp 0.88=2.41)$. In 1980 and 1990 we see a decline in the coefficient, however it remains positive and significant in both years-in 1990 the founders still traded over 75 percent more with each other than

\footnotetext{
${ }^{18}$ The trade data is from the IMF Direction of Trade Statistics database. The GNP and GNP per capita data are from the World Bank CD STARS, except for 1954, which is calculated from the IMF International Financial Statistics. The distance data is from the world distance tables and is the direct air distance between economic centers.
} 
is predicted by the gravity model. The positive coefficient in 1954 suggests that so far we cannot rule out the possibility that the union was formed along natural trade lines. There is one caveat, in 1954 the founding six had already begun the process of forming a free trade arrangement-they created the European Coal and Steel Community (ECSC) in 1951, which formed a customs union in these products. ${ }^{19}$ Ideally, we would like to explore the gravity model before 1951. Eichengreen and Irwin have gone some way towards this. In a sample of 38 countries, they find that in 1949 the founding six did not trade more with each other, in fact the coefficient on EEC, which is a dummy variable representing the members in 1949, is negative though not significant. In addition, they find that the coefficient on the EEC grows over the years, their results for the coefficient on EEC in 1954 and 1964 of 0.18 and 0.63 , respectively, are consistent with ours. ${ }^{20}$ They also include lagged trade in the regression equation and find it to be significant in each year, they interpret this as evidence that history is an important determinant of trade flows.

Since Spain and Portugal were the last countries to join the Union, we also include a dummy variable called $L A T E$ that is one when either of these countries participates in trade. The theory above suggests that the coefficient on $L A T E$ should be negative in 1980 and 1990, since Spain and Portugal had less access to foreign markets and foreign countries had less of an incentive to expand exports to Spain and Portugal. The results are recorded in columns 6-10 of Table 1. In 1990, Spain and Portugal traded about $45 \%$ less with the other members of the Union than is predicted by the gravity model. This case, however, is also consistent with the natural trade partners hypothesis, since Spain and Portugal trade

\footnotetext{
${ }^{19}$ In addition, Belgium, Luxembourg and the Netherlands formed a customs union in 1948.

${ }^{20}$ Eichengreen and Irwin do not explore data after 1964.
} 
significantly less throughout the years. ${ }^{21}$ Not surprisingly, the coefficient on $O R G$ declines when $L A T E$ is included in the regression, since part of the increased trade among the original members is a result of their trading less with Spain and Portugal. Still, the coefficient on $O R G$ is increasing through 1970 and decreasing after and remains positive and significant in 1990.

In addition, owing to past colonial links, we include a dummy variable to represent trade between Ireland and Britain, entitled $C O L$. The coefficient on $C O L$ is likely to be positive. The results presented in Table 1 suggest that Britain and Ireland still traded more than twice as much with each other than with the other members in 1990.

Heckscher-Ohlin theory suggests that the coefficient on DIFPC should be positive, implying that as the distance between two countries' per capita incomes and thus capital intensities expands, trade increases. The results in Table 1 show that the coefficient on $D I F P C$ is positive in all years and significant in the later years. Frankel, Stein, and Wei also use DIFPC to proxy for H-O trade and find it to be insignificant in 1990 in a sample of 63 countries. Heckscher-Ohlin theory requires that countries have identical technologies, that all countries produce all goods, and that goods and factor prices are equalized. In our sample of European countries these assumptions are more realistic than in a wider sample, especially in the later years when there are no trade barriers among the nations in the sample. $^{22}$

\footnotetext{
${ }^{21}$ The magnitude of the coefficient in 1954 is due primarily to autarkic domestic policies in Spain before their Stabilization Plan of 1959.

${ }^{22}$ In addition to the reported regressions, we included a variable for remoteness-how far are countries from their trading partners-calculated as the sum of DIST $/ \mathrm{Y}_{j}$ for all trading partners, which was not significant.
} 
A final way to distinguish the hysteresis hypothesis from the natural trade partners hypothesis is to use past trade as a proxy for initial conditions. We include past values of the dependent variable from 1950 in the regression equation. ${ }^{23}$ The results are recorded in Table 2. All of the coefficients decline in both magnitude and significance. For example, the coefficient on distance falls close to zero in 1962, indicating that distance affects trade in roughly the same way in the two periods. Not surprisingly, the importance of the initial conditions declines over time, however, trade patterns in 1950 are still highly significant in determining trade in 1990. Even accounting for initial conditions, the coefficient on $O R G$ is still highly significant in 1962, 1970, 1980, and $1990 .{ }^{24}$

The empirical results from this section are consistent with the hypothesis that the founding members of a union retain a relatively greater share of each others' markets after other countries are granted equal market access. While there is little evidence that the original members traded more with each other before the union was established, the original members of the EU trade more with each other than is predicted by the gravity model in the years since its formation. The importance of being a founding member is confirmed at the industry level as well; industry data shows the original members trading $73 \%$ more with We also tried including dummies for importer and then for exporter countries, and found qualitatively similar results.

${ }^{23}$ This is different from what Eichengreen and Irwin did. They use lagged trade from about ten years before in each regression equation.

${ }^{24}$ The regression including past trade was also run on 1954 trade values. In addition, it was tried in trade levels, as opposed to log levels. In both cases the results still hold. When it was run in levels, while $O R G$ was still highly significant in each year $C O L$ was never significant and $L A T E$ was not significant in 1962 and 1970 . 
each other than the gravity model predicts in 1990. Moreover, in the same five out of nine industries the original members trade significantly more with each other than is predicted by the gravity model in both 1980 and $1990 .^{25}$

\section{Conclusions}

The equilibrium free trade outcome arising from a regional agreement followed by free trade may be different from the outcome attained through multilateral negotiation. The logic is quite simple, if there are large sunk costs involved in setting up a distribution network, firms can effectively pre-commit to exports. As a result, regionalism provides firms in the early entrant nations with first mover advantages. This leads to higher welfare in the member nations than without the regional agreement.

Welfare expands because of the effect of the regional agreement on competition. With imperfect competition output is too low. Trade helps to alleviate this distortion. The initiation of a regional agreement before allowing free trade reduces the distortion further by introducing a strategic incentive to expand output. Sunk costs allow firms from a member nation to commit to exporting more to their partner than they would if they acted simultaneously with firms from a third country. Because of this expansion in output, consumer surplus in the free trade period after a regional agreement and profits from exports are greater than if there had been two periods of free trade.

The allotment of benefits from the regional path is skewed. While the initial members actually achieve higher welfare from the regional path than they would have had free trade

\footnotetext{
${ }^{25}$ The industry level results were reported in an earlier version of the paper and are available upon request.
} 
been reached multilaterally, late entrants attain a lower welfare level from the regional path to free trade than from the multilateral negotiation path. Surprisingly, world welfare during the period of free trade is higher from the regional path.

We go on to examine some of the implications of the model for the European Union, adjusting for the natural determinants of trade using the gravity equation. The main results are consistent with the hypothesis that early entry into a trade union allows countries to establish trade links that persist over time. While there is no evidence that the founding members traded more with each other before the union was established, by 1970 they were trading more than twice as much with each other as with the non-members. Moreover, the six countries that established the Community in 1958, continued to trade over $75 \%$ more with each other in 1990 than the gravity model predicts. The model also suggests that late entrants should be at a relative disadvantage. Aggregate trade data shows the most recent entrants to the EU trading significantly less with the other members in 1990. In this case, however, the late entrants trade less at the aggregate level in all of the years suggesting that the bias may be natural, rather than a result of the union.

\section{Appendix}

\subsection{C prefers free trade in both periods}

If $\mathrm{C}$ does not allow imports it earns:

$$
\text { Profits in } C=\Pi_{C}^{C}=(1+\beta) \frac{n(K-w-x)}{(n+1)^{2}}
$$




$$
\text { Consumer surplus }=S_{C}=\left(\frac{1+\beta}{2}\right)\left[\frac{(K-w-x) n}{(n+1)}\right]^{2} .
$$

If $\mathrm{C}$ permits imports in both periods, we have:

$$
\begin{gathered}
\text { Profits in } C=\Pi_{C}^{C^{*}}=(1+\beta) \frac{n(K-w-x)}{(n+1)^{2}(2 n+1)} \\
\text { Consumer surplus }=S_{C^{*}}=\left(\frac{1+\beta}{2}\right)\left[\frac{(K-w-x)\left(2 n^{2}+3 n\right)}{(n+1)(2 n+1)}\right]^{2} .
\end{gathered}
$$

\subsection{Welfare in A from Regionalism}

$$
\begin{gathered}
\text { Profits at home }=\Pi_{A}^{A}=\frac{n(K-w-x)^{2}}{(n+1)^{3}}+\frac{\beta n(K-w-x)^{2}}{(n+1)^{4}} \\
\text { Profits in } B=\Pi_{A}^{B}=\frac{n(K-w-x)^{2}}{(n+1)^{4}}+\frac{\beta n(K-w-x)^{2}}{(n+1)^{5}} \\
\text { Profits in } C=\Pi_{A}^{B}=(1+\beta) \frac{n(K-w-x)^{2}}{(n+1)^{2}(2 n+1)^{2}}
\end{gathered}
$$

Consumer surplus at home $=$

$$
\frac{1}{2}\left[\left[\frac{(K-w-x)\left(n^{2}+2 n\right)}{(n+1)^{2}}\right]^{2}+\beta\left[\frac{(K-w-x)\left(n^{3}+3 n^{2}+3 n\right)}{(n+1)^{3}}\right]^{2}\right]
$$

\subsection{Welfare in C from Regionalism}

$$
\begin{gathered}
\text { Profits in } A \text { (same as profits in } B)=\Pi_{C}^{A}=\Pi_{C}^{B}=\beta\left(\frac{n(K-w-x)^{2}}{(n+1)^{6}}\right) \\
\text { Profits in } C=\Pi_{C}^{C^{*}}=(1+\beta) \frac{n(K-w-x)^{2}}{(n+1)^{2}(2 n+1)} \\
\text { Consumer surplus }=\frac{(1+\beta)}{2}\left[\frac{(K-w-x)\left(2 n^{2}+3 n\right)}{(n+1)(2 n+1)}\right]^{2} \\
\text { Welfare in } C=W_{C}^{R}=\Pi_{C}^{A}+\Pi_{C}^{B}+\Pi_{C}^{C}+S_{C} .
\end{gathered}
$$




\subsection{Welfare from multilateralism}

$$
\text { Profits in } A=\Pi_{A}^{A}=(1+\beta) \frac{n(K-w-x)^{2}}{(n+1)^{2}(2 n+1)}
$$

Profits in $B$ (same as profits in $C)=\Pi_{A}^{B}=\Pi_{A}^{C}=(1+\beta) \frac{n(K-w-x)^{2}}{(n+1)^{2}(2 n+1)^{2}}$

$$
\text { Consumer surplus }=\frac{(1+\beta)}{2}\left[\frac{(K-w-x)\left(2 n^{2}+3 n\right)}{(n+1)(2 n+1)}\right]^{2}
$$

Welfare in $A=W_{A}^{M N}=\Pi_{A}^{A}+\Pi_{A}^{B}+\Pi_{A}^{C}+S_{A}$.

7.5 Country in regional agreement always wants free trade in second period

$$
\text { Welfare from regionalism in } A=W_{A}^{R}=\Pi_{A}^{A}+\Pi_{A}^{B}+\Pi_{A}^{C}+S_{A} \text {. }
$$

$W_{A}^{B L}$ is the welfare from a bilateral agreement in both periods, then

$$
\begin{gathered}
W_{A}^{R}-W_{A}^{B L}=\beta \frac{n(K-w-x)^{2}}{(n+1)^{5}}-\beta \frac{n(K-w-x)^{2}}{(n+1)^{3}}+\frac{1}{2} \beta \frac{(K-w-x)^{2}\left(2 n^{4}+6 n^{3}+5 n^{2}\right)}{(n+1)^{6}} \\
=\beta \frac{(K-w-x)^{2} n^{2}}{2(n+1)^{6}}>0 .
\end{gathered}
$$

7.6 Welfare from Regionalism in A is better than multilateralism even if country $\mathrm{C}$ excludes $\mathrm{A}$ and $\mathrm{B}$ in the first period

$$
W_{A}^{R}-W_{A}^{M N}=(K-w-x)^{2} \frac{\left(-2-7 n+2 \beta n-8 n^{2}+8 \beta n^{2}-3 n^{3}+9 \beta n^{3}+2 \beta n^{4}\right)}{2(1+n)^{6}(1+2 n)^{2}},
$$


if $\beta=1$, becomes:

$$
(K-w-x)^{2} \frac{\left(-2-5 n+6 n^{3}+2 n^{4}\right)}{2(1+n)^{6}(1+2 n)^{2}}
$$

which is increasing in $n$ and is $>0$ at $n=1$. If $n=1$, it is positive provided $\beta>20 / 21$. Hence it must also be higher when $\mathrm{C}$ allows firms from $\mathrm{A}$ and $\mathrm{B}$ into their market.

7.7 The present discounted value of world welfare is greater after multilateralism than after regionalism if $\beta \leq 1$

$$
\begin{aligned}
& W_{A}^{R}+W_{B}^{R}+W_{C}^{R}-3 W^{M N} \\
= & (K-w-x)^{2} \frac{n\left(-2-7 n+2 \beta n-8 n^{2}+4 \beta n^{2}-3 n^{3}+\beta n\right.}{(1+n)^{6}(1+2 n)^{2}}<0
\end{aligned}
$$

for all $n>1$ and $0<\beta \leq 1$.

7.8 World welfare in the second period after regionalism is always greater than world welfare in the second period from multilateralism

$$
W_{2}^{R}-W_{2}^{M N}=(K-w-x)^{2} \frac{\beta n^{2}\left(2+4 n+n^{2}\right)}{(1+n)^{6}(1+2 n)^{2}}>0
$$

for all $n>0$.

\subsection{Cost differences}

$$
\frac{d W}{d w_{B}}=\frac{-764 w_{A}+466 w_{B}+201 w_{C}+97(K-x)}{288},
$$




$$
\begin{gathered}
\frac{d W}{d w_{C}}=\frac{-316 w_{A}+134 w_{B}+135 w_{C}+47(K-x)}{192} \\
\frac{d W}{d w_{B}}-\frac{d W}{d w_{C}}=\frac{-580 w_{A}+530 w_{B}-3 w_{C}+53(K-x)}{576}>0 .
\end{gathered}
$$

As long as all firms are producing, and the cost of the firm from $\mathrm{A}$ is not too much greater than the others, each of these must be greater than 0 , since $\mathrm{K}-\mathrm{w}-\mathrm{x}>0$. Notice that in each case if the costs were equal the numerator would be $\mathrm{c}(\mathrm{K}-\mathrm{x}-\mathrm{w})$, where $\mathrm{c}$ is a constant. 
Table 1: Gravity equation by year

\begin{tabular}{|c|c|c|c|c|c|c|c|c|c|c|}
\hline & 1954 & 1962 & 1970 & 1980 & 1990 & 1954 & 1962 & 1970 & 1980 & 1990 \\
\hline GNP & $\begin{array}{l}0.61 * * \\
(0.07)\end{array}$ & $\begin{array}{l}0.66 * * \\
(0.06)\end{array}$ & $\begin{array}{l}0.75 * * \\
(0.06)\end{array}$ & $\begin{array}{l}0.71 * * \\
(0.04)\end{array}$ & $\begin{array}{l}0.75 * * \\
(0.04)\end{array}$ & $\begin{array}{l}0.67 * * \\
(0.07)\end{array}$ & $\begin{array}{l}0.71 * * \\
(0.06)\end{array}$ & $\begin{array}{l}0.79 * * \\
(0.06)\end{array}$ & $\begin{array}{l}0.78 * * \\
(0.04)\end{array}$ & $\begin{array}{l}0.80 * * \\
(0.04)\end{array}$ \\
\hline PCGNP & $\begin{array}{l}0.17 \\
(0.24)\end{array}$ & $\begin{array}{l}0.47 * * \\
(0.18)\end{array}$ & $\begin{array}{l}0.22 \\
(0.19)\end{array}$ & $\begin{array}{l}0.05 \\
(0.17)\end{array}$ & $\begin{array}{l}-0.48 * * \\
(0.14)\end{array}$ & $\begin{array}{l}-0.29 \\
0.30\end{array}$ & $\begin{array}{l}0.09 \\
(0.25)\end{array}$ & $\begin{array}{l}-0.14 \\
(0.25)\end{array}$ & $\begin{array}{l}-0.36^{*} \\
(0.18)\end{array}$ & $\begin{array}{l}-0.70 * * \\
(0.15)\end{array}$ \\
\hline DIS & $\begin{array}{l}-0.65^{*} \\
(0.30)\end{array}$ & $\begin{array}{l}-0.41 * \\
(0.20)\end{array}$ & $\begin{array}{l}-0.54 * * \\
(0.21)\end{array}$ & $\begin{array}{l}-0.78^{* *} \\
(0.18)\end{array}$ & $\begin{array}{l}-0.87 * * \\
(0.12)\end{array}$ & $\begin{array}{l}-0.66 \\
(0.31)\end{array}$ & $\begin{array}{l}-0.37 \\
(0.20)\end{array}$ & $\begin{array}{l}-0.46^{*} \\
(0.19)\end{array}$ & $\begin{array}{l}-0.64 * * \\
(0.16)\end{array}$ & $\begin{array}{l}-0.75^{* *} \\
(0.11)\end{array}$ \\
\hline ADJ & $\begin{array}{l}0.07 \\
(0.31)\end{array}$ & $\begin{array}{l}0.37 \\
(0.24)\end{array}$ & $\begin{array}{l}0.23 \\
(0.22)\end{array}$ & $\begin{array}{l}0.09 \\
(0.18)\end{array}$ & $\begin{array}{l}0.17 \\
(0.16)\end{array}$ & $\begin{array}{l}0.24 \\
(0.28)\end{array}$ & $\begin{array}{l}0.49 * \\
(0.23)\end{array}$ & $\begin{array}{l}0.42 \\
(0.22)\end{array}$ & $\begin{array}{l}0.34 * \\
(0.16)\end{array}$ & $\begin{array}{l}0.34^{*} \\
(0.14)\end{array}$ \\
\hline DIFPC & $\begin{array}{l}0.17 \\
(0.13)\end{array}$ & $\begin{array}{l}0.15 \\
(0.08)\end{array}$ & $\begin{array}{l}0.15 \\
(0.13)\end{array}$ & $\begin{array}{l}0.13 * * \\
(0.04)\end{array}$ & $\begin{array}{l}0.17 * * \\
(0.05)\end{array}$ & $\begin{array}{l}0.23 \\
(0.15)\end{array}$ & $\begin{array}{l}0.15^{*} \\
(0.08)\end{array}$ & $\begin{array}{l}0.18 \\
(0.11)\end{array}$ & $\begin{array}{l}0.12 * * \\
(0.04)\end{array}$ & $\begin{array}{l}0.16^{* *} \\
(0.04)\end{array}$ \\
\hline ORG & $\begin{array}{l}0.36 \\
(0.24)\end{array}$ & $\begin{array}{l}0.51 * \\
(0.20)\end{array}$ & $\begin{array}{l}0.88 * * \\
(0.16)\end{array}$ & $\begin{array}{l}0.62 * * \\
(0.13)\end{array}$ & $\begin{array}{l}0.58 * * \\
(0.15)\end{array}$ & $\begin{array}{l}0.10 \\
(0.26)\end{array}$ & $\begin{array}{l}0.39 \\
(0.21)\end{array}$ & $\begin{array}{l}0.82 * * \\
(0.16)\end{array}$ & $\begin{array}{l}0.44 * * \\
(0.13)\end{array}$ & $\begin{array}{l}0.42^{* *} \\
(0.14)\end{array}$ \\
\hline $\mathrm{COL}$ & & & & & & $\begin{array}{l}1.51 * * \\
(0.36)\end{array}$ & $\begin{array}{l}1.52 * * \\
(0.26)\end{array}$ & $\begin{array}{l}1.71 * * \\
(0.28)\end{array}$ & $\begin{array}{l}1.07 * * \\
(0.22)\end{array}$ & $\begin{array}{l}0.80 * * \\
(0.13)\end{array}$ \\
\hline LATE & & & & & & $\begin{array}{l}-0.91 * * \\
(0.29)\end{array}$ & $\begin{array}{l}-0.63 * \\
(0.26)\end{array}$ & $\begin{array}{l}-0.62 * \\
(0.26)\end{array}$ & $\begin{array}{l}-0.91 * * \\
(0.17)\end{array}$ & $\begin{array}{l}-0.56^{* *} \\
(0.15)\end{array}$ \\
\hline $\begin{array}{l}\text { No. of obs. } \\
\text { Adj R-square }\end{array}$ & $\begin{array}{l}106 \\
0.65\end{array}$ & $\begin{array}{l}107 \\
0.78\end{array}$ & $\begin{array}{l}110 \\
0.82\end{array}$ & $\begin{array}{l}110 \\
0.85\end{array}$ & $\begin{array}{l}110 \\
0.88\end{array}$ & $\begin{array}{l}106 \\
0.68\end{array}$ & $\begin{array}{l}107 \\
0.79\end{array}$ & $\begin{array}{l}110 \\
0.83\end{array}$ & $\begin{array}{l}110 \\
0.88\end{array}$ & $\begin{array}{l}110 \\
0.90\end{array}$ \\
\hline
\end{tabular}


Table 2: Gravity equation with initial conditions

\begin{tabular}{|c|c|c|c|c|}
\hline & 1962 & 1970 & 1980 & 1990 \\
\hline GNP & $\begin{array}{l}0.37 * * \\
(0.06)\end{array}$ & $\begin{array}{l}0.42 * * \\
(0.06)\end{array}$ & $\begin{array}{l}0.55 * * \\
(0.05)\end{array}$ & $\begin{array}{l}0.67 * * \\
(0.05)\end{array}$ \\
\hline PCGNP & $\begin{array}{l}-0.08 \\
(0.15)\end{array}$ & $\begin{array}{l}-0.30 \\
(0.18)\end{array}$ & $\begin{array}{l}-0.36^{*} \\
(0.16)\end{array}$ & $\begin{array}{l}-0.71^{* *} \\
(0.16)\end{array}$ \\
\hline DIS & $\begin{array}{l}-0.06 \\
(0.11)\end{array}$ & $\begin{array}{l}-0.11 \\
(0.13)\end{array}$ & $\begin{array}{l}-0.41^{* *} \\
(0.14)\end{array}$ & $\begin{array}{l}-0.58^{* *} \\
(0.11)\end{array}$ \\
\hline ADJ & $\begin{array}{l}0.24 \\
(0.16)\end{array}$ & $\begin{array}{l}0.30 \\
(0.16)\end{array}$ & $\begin{array}{l}0.30 \\
(0.13)\end{array}$ & $\begin{array}{l}0.33 * * \\
(0.12)\end{array}$ \\
\hline EXP50 & $\begin{array}{l}0.64 * * \\
(0.06)\end{array}$ & $\begin{array}{l}0.51 * * \\
(0.08)\end{array}$ & $\begin{array}{l}0.33 * * \\
(0.06)\end{array}$ & $\begin{array}{l}0.19 * * \\
(0.06)\end{array}$ \\
\hline DIFPC & $\begin{array}{l}0.10 \\
(0.05)\end{array}$ & $\begin{array}{l}0.15 \\
(0.12)\end{array}$ & $\begin{array}{l}0.12^{*} \\
(0.04)\end{array}$ & $\begin{array}{l}0.15^{* *} \\
(0.05)\end{array}$ \\
\hline ORG & $\begin{array}{l}0.35^{*} \\
(0.14)\end{array}$ & $\begin{array}{l}0.91^{* *} \\
(0.20)\end{array}$ & $\begin{array}{l}0.47 * * \\
(0.11)\end{array}$ & $\begin{array}{l}0.44 * * \\
(0.12)\end{array}$ \\
\hline $\mathrm{COL}$ & $\begin{array}{l}0.38 * * \\
(0.14)\end{array}$ & $\begin{array}{l}0.53 * * \\
(0.20)\end{array}$ & $\begin{array}{l}0.36 \\
(0.19)\end{array}$ & $\begin{array}{l}0.46 * * \\
(0.14)\end{array}$ \\
\hline LATE & $\begin{array}{l}-0.34 * \\
(0.16)\end{array}$ & $\begin{array}{l}-0.44^{*} \\
(0.06)\end{array}$ & $\begin{array}{l}-0.72 * * \\
(-0.16)\end{array}$ & $\begin{array}{l}-0.42 * * \\
(0.15)\end{array}$ \\
\hline No. of obs. & 100 & 100 & 100 & 100 \\
\hline Adj R-square & 0.91 & 0.90 & 0.90 & 0.90 \\
\hline \multicolumn{5}{|c|}{$\begin{array}{l}\text { Regressions were run with a constant term, values for } \\
\text { constants are not reported. } \\
\text { Heteroskedasticity consistent standard errors are in } \\
\text { parentheses (White 1980). } \\
\text { ** Significant at the } 1 \% \text { level. *Significant at the 5\% } \\
\text { level. }\end{array}$} \\
\hline
\end{tabular}




\section{References}

Bagwell, K. and R. Staiger. "Multilateral Tariff Cooperation During the Formation of Customs Unions." Journal of International Economics, 42, 1997, pp. 91-123.

Baldwin, R. “A Domino Theory of Regionalism.” NBER working paper \#4465, 1993.

Baldwin, R. and P. Krugman. "Persistent Effects of Large Exchange Rate Shocks." The Quarterly Journal of Economics, November 1989, pp. 635-654.

Bhagwati, J. "Regionalism and Multilateralism: an Overview." In A. Panagariya and J. De Melo Eds., New Dimensions in Regional Integration, Oxford Univ. Press, 1993.

Brander, J. and P. Krugman. "A 'Reciprocal Dumping' Model of International Trade." Journal of International Economics 15, November 1983, pp. 313-323.

Brander, J. and B. Spencer. "Export Subsidies and International Market Share Rivalry." Journal of International Economics, 18, 1985, pp. 83-100.

Bond, E. and C. Syropoulos. "The Size of Trading Blocs Market Power and World Welfare Effects." Journal of International Economics, 40, 1996, pp. 411-437.

Campa, J. "Entry by Foreign Firms in the United States Under Exchange Rate Uncertainty." The Review of Economics and Statistics, 75(4), 1993, pp. 614-622.

Dixit, A. "The Role of Investment in Entry-Deterrence." The Economic Journal, 90, 1980, pp. 95-106.

Dixit, A. "Hysteresis, Import Penetration, and Exchange Rate Pass-Through." The Quarterly Journal of Economics, May 1989, pp. 205-228.

Eichengreen, B. and D. Irwin. "The Role of History in Bilateral Trade flows." NBER working paper \#5565, May 1996, pp. 942-958.

Engel, C. and J. Rogers. "Regional Patterns in the Law of One Price: The Roles of Geography Vs. Currencies.” International Finance Discussion Papers, \#533, January 1996.

Feinberg, R. "Hysteresis and Export Targeting." International Journal of Industrial Organization, 10, 1992, pp. 679-684.

Frankel, J., E. Stein, and S. Wei. "Trading Blocs and the Americas: The Natural the Unnatural and the Supernatural." Journal of Development Economics, 47, 1995, pp. 6195. 
Grossman, G. and E. Helpman, "The Politics of Free Trade Agreements." American Economic Review, September, 1995, pp. 667-690.

Haveman, J. "Some Welfare effects of Sequantial Customs Union Formation." Canadian Journal of Economics, November 1996, pp.941-958.

Kennan, J. and R. Riezman. "Optimal Tariff Equilibria with Customs Unions." Canadian Journal of Economics, February 1990, p. 70-83.

Krishna, P. "Regionalism and Multilateralism: A Political Economy Approach." Ph.D. Dissertation, Columbia University, 1994.

Krugman, P. "Is Bilateralism Bad?" In Helpman and Razin, eds., International Trade and Trade Policy, MIT Press, 1992.

Levy, P. "A Political Economic Analysis of Free Trade Agreements." Center for Economic Policy Research Paper, No. 347, January 1993.

Maggi, G. "Strategic trade Policies with Endogenous Mode of Competition." American Economic Review, March 1996, pp. 237-258.

McLaren, J. "Size, Sunk Costs, and Judge Bowker's Objection to Free Trade." American Economic Review, June 1997, pp. 400-421.

Roberts, M. and J. Tybout. "The Decision to Export in Columbia: An Empirical Model of Entry with Sunk Costs." American Economic Review, September 1997, pp. 545-564.

Richardson, M. "Endogenous Protection and Trade Diversion." Journal of International Economics, 34, 1993, pp. 309-324. 